\title{
EXTERNAL AUDIT SYSTEMS
}

Stoica Petrică, Economist

\begin{abstract}
:
The present article has as objective the presentation of a series of external audit systems, together with some of their characteristics and models found in different countries.

The purpose of the external audit performed by the Supreme Audit Institutions (SAI) is to assure the proper use of the public funds, a good management and the public and private accountability of the authorities, through the published objective rapports.
\end{abstract}

The public sector audit represents a crucial element within an effective accountability framework met in all demographic governments.

The modern audits of the public sector are first of all geared towards the needs of the legislature.

However, these add a significant value to public sector management, by providing the objective and professional evaluation of the efficacy of the financial management system and of the economy, and efficiency and effectiveness in the operations performed by the government.

In most countries, a supreme audit institution (SAI) conducts public sector auditing.

The structure, function, and the status of the SAI may vary from country to country due to their respective historic development, political systems, culture, language and regional affiliations.

In advanced European and American nations it has been introduced a mechanism regarding the approach oriented towards the client performance and market principles which should work effectively.

Accountability for the use of public funds is a cornerstone of good public financial management.

Supreme Audit Institutions (SAIs) are the national bodies responsible for scrutinizing public expenditure which provide an independent opinion on how the executive has used public resources.

The four objectives of public sector auditing are to promote:

public funds; the proper and effective use of

- $\quad$ the development of a powerful financial management; administrative activities;

the communication of information to public authorities and the general public through the publication of objective reports.

These fundamental objectives guide the work of all Supreme Audit Institutions but several different public external audit models exist around the world.

However, every country is different and even where a Supreme Audit Institution broadly follows one of these audit models, there are likely to be some national variations in its remit and the way it is organized.

The three external audit models are the following: 


\begin{tabular}{|c|l|}
\hline External audit model & \multicolumn{1}{|c|}{ Distribution } \\
\hline $\begin{array}{c}\text { Westminster model, also known as the } \\
\text { Anglo-Saxon or Parliamentary model }\end{array}$ & $\begin{array}{l}\text { The United Kingdom, some European } \\
\text { countries as for example Ireland and } \\
\text { Denmark, Latin American } \\
\text { countries such as Peru and Chile }\end{array}$ \\
\hline Judicial or Napoleonic model & $\begin{array}{l}\text { The Latin countries from Europe, Turkey, } \\
\text { francophone countries from Africa and } \\
\text { Asia, several Latin American countries } \\
\text { including Brazil and Colombia }\end{array}$ \\
\hline Board or Collegiate model & $\begin{array}{l}\text { Some European countries including } \\
\text { Germany and the } \\
\text { Netherlands, Argentina, } \\
\text { Indonesia, Japan and the Republic of } \\
\text { Korea }\end{array}$ \\
\hline
\end{tabular}

Table no.1- External audit models

Westminster Model

The Public Financial Management is currently in the process of developing more detailed guidance to assist Country Offices in assessing the maturity and performance of individual Supreme Audit Institutions and formulating pragmatic approaches to improve their effectiveness.

According to the Westminster model, the work of the Supreme Audit Institutions (SAIs) is intrinsically linked to the system of parliamentary accountability.

The basic elements of such a system are:

- authorization of expenditure by Parliament;

- elaboration of annual accounts by all departments, government and other public bodies;

- the audit of those accounts by the Supreme Audit Institutions;

- the submission of audit reports to Parliament ;

- issue of reports and/or recommendations by the Public Accounts Committee (PAC);

- Government response to the Public Accounts Committee reports.

Westminster accountability systems have the following characteristics:

- a National Audit Office (NAO) with a single head, often called the Auditor General, who may be an officer of Parliament
- all rights, powers and responsibilities vested in the Auditor General personally, rather than in the NAO as an institution;

- staff who have a professional financial background - accountants and auditors;

- a strong focus on financial audit and on the value for money with which audited bodies have used their resources, with less emphasis on compliance with legislative provisions;

- a mechanism, whether formal or by convention, whereby the Government is required to respond to Public Accounts Committee reports and state the actions it is taking to implement recommendations.

According to this system the role of the General Auditor may be combined with that of a Comptroller.

His function is one of control rather than audit and it is performed prior the execution of the expenditure.

The Comptroller is required to authorize Ministry of Finance requisitions from central funds.

Before authorizing such requisitions, the Comptroller must obtain assurance that these credits are requested for purposes which have legal authority and are within the financial limits approved by the Parliament.

Checks relating to the Comptroller function are normally performed at a high level and do not involve a detailed review of analytical expenditure. 


\section{Judicial Model}

According to this model, the Supreme Audit Institution is an integral part of the judicial system operating independently of the executive and legislative branches.

It is possible for the Supreme Audit Institutions that use this model, to have only a limited relationship with the national parliament.

A key aspect of judicial accountability systems is that relevant government officials are usually held personally liable for the sums involved should an unauthorized or illegal payment be made.

In addition to the SAI's judicial role, a complementary high level system of parliamentary accountability for public expenditure is normally in place.

The key elements of a judicial system are:

- at national level, the Parliament authorizes public spending in the annual budget;

- the officials of the Ministry of Finance are transferring funds towards other ministries and institutions, and supervise the accounting procedures. They individually prepare the financial situations which are being audited by the Supreme Audit Institution;

- the Ministry of Finance normally plays an active role both in setting rules for public accountants and other officials to follow and in checking that these rules are being compiled with. It may exercise a strong 'internal audit' role, in the sense that auditors from the Ministry of Finance are internal to government as a whole, even though they are external to the body being audited.

- The Supreme Audit Institution audits the annual financial statements prepared by the public accountants.

- often, SAI is empowered to audit several years of accounts simultaneously, rather than auditing every set of financial statements, every year. This is the reason for which it seldom adopts a cyclical approach to their work, particularly for smaller and lower spending entities.

- for this purpose SAI judges the legality of the public accountant's actions and can :
- "discharge" - the public accountant from further liability if it is considered that the transactions are legal;

- Impose a penalty where illegal transactions are found.

The Supreme Audit Institution normally presents a report on the State Account to Parliament, insisting upon the most important issues identified in the audit of individual public accountants as well as upon analytical review procedures.

The Parliament can rely on this report in granting a 'discharge' of responsibility to the government for the year, if it is satisfied with the way the government has managed public funds in the year.

The main characteristics of a judicial audit model are:

- the Supreme Audit Institution is a Court and its Members are judges who can impose penalties or corrections on audited officials;

- there are important safeguards in what concerns the independence of the Members of the Court who are usually appointed for a non time-limited term until a fixed retirement age;

- the Court normally selects a Member to act as its president. However, all members have independent judicial status and the authority to rule on the cases in front of them;

- the main objective of the audit activity is to verify the legality of the transactions which take place;

- the professional staff from this kind of SAI tend to have legal rather than accounting or auditing backgrounds.

There can be variations from one country to another within the judicial model described above. The most important is that in some countries - particularly Portugal and Italy - the SAIs may have an ex ante control function as well as an ex post audit function.

This means that the Supreme Audit Institution is responsible for checking and giving prior approval to certain types of public expenditure.

The ex ante function is normally performed by a separate court or division within the SAI and in contrast to the 
Westminster model, it usually involves a more detailed level of checks.

\section{Collegiate or Board Model}

According to the collegiate or board system, the Supreme Audit Institution has a number of members who form its college or governing board and take decisions jointly.

Collegiate audit bodies are usually part of a parliamentary system of accountability.

Reports and opinions agreed by the college are submitted to Parliament, where there is usually some form of Public Accounts Committee to act on them. Collegiate bodies do not have judicial functions.

The basic structure of the accountability model is thus similar to the Westminster model, with the key differences being in the internal structure of the audit institution.

The main characteristics of this model are:

- a governing committee consisting of the members of the college and run by a president;

- depending on the size of the office, there may be a series of colleges or subcommittees each having the power to decide on the audit matters within their area of responsibility. There is usually also some sort of appeals committee to review contested decisions of individual colleges;

- members normally have considerable freedom in determining their working methodologies and there may be a variety of audit approaches between different colleges within the same institution;

- members of the college are normally appointed for a fixed term by a vote of Parliament, and have a limited number of mandates, maximum two;

- the objective of the SAI's work "financial or legal" is less influenced by the fact that it is a collegiate institution, than by the general legislative and historical context of the country it operates in.

Beyond the three main external audit models, it has to be mentioned the fact that, in some countries, an independent external audit institution may not actually exist, while in other countries it may exist an external audit system which, for historic reasons incorporates elements from more than one model of financial accountability.

It is possible that a country may not have any external audit function at all, and this can certainly occur in non-democratic regimes where power is centralized within the executive branch.

Alternatively, an 'external auditor' may exist but it will certainly be part of the executive rather than independent of government.

Before rushing in with a standard model based on one of the existing systems, careful analysis of the current system and traditions of the country needs to be undertaken.

Consideration needs to be given to what is working within the existing system, what is not working and how an independent SAI could best build on what is there already.

Even if the existing audit body is not fully independent of the government, it may be operating in reasonably autonomous way and there may be elements worth preserving.

A country's Supreme Audit Institution, and all of its financial accountability systems, may incorporate elements of different systems which can be incompatible and ineffective

The overlapping of the audit models is potentially one of the most difficult situations to resolve and will probably have ramifications extending well beyond the SAI itself.

\section{References:}

[1] Cogliandro, G., The Audit System, in "International Journal of Public Administration" 2000, volume 23, numbers $2 \& 3$;

[2] Borge, Magnus, "The role of Supreme Audit Institutions (SAIs) in Combating Corruption" 2005 ; 
[3] Association of Chartered Certified Accountants. "Different Models of Supreme Audit Institutions". Updated 2005. Retrieved 21 April 2005

http://www.accaglobal.com/ transparency/ publicsector/audit/models;

[4] Borge, Magnus. "The role of Supreme Audit Institutions (SAIs) in Combating Corruption." Transparency International Updated October 1999. Retrieved 8 February2005

[5] http://www.transparency.org/iacc/9th_iacc/papers/day4/ws2/d4ws2_mborge.html;

[6] International Organization of Supreme Audit Institutions. "The Lima Declaration of Guidelines on Auditing Precepts." Updated 2005. Retrieved 8 February 2005

[7] <http://www.intosai.org/Level2/2_LIMADe.html>. 